\title{
Table of legal instruments
}

(in chronological order)

\section{A. Treaties}

Treaty between Spain and Portugal concluded at Tordesillas, 7 June 1494 49,68

Treaty between Spain and Portugal, concluded at Vitoria, 19 February 1524 .................... 47, 50

Treaty between France and Spain concluded at Cateau-Cambrésis, 3 April 1559 .................... 70

Treaty of Peace with Necotowance, King of the Indians, 5 October 1646 ............................. 130

Peace of Westphalia (1648) ...................................................................................................... 265

Peace of Münster between the Dutch Republic and the Kingdom of Spain, 30 January 1648,

1 C.T.S. 1 70,265

Treaty of Münster (Instrumentum Pacis Monasteriensis, IPM), concerning the Holy Roman

Emperor and France and their respective allies, 24 October 1648, 1 C.T.S. 319-56 ..... 266

Treaty of Osnabrück (Instrumentum Pacis Osnabrugensis, IPO), concerning the Holy Roman

Empire, the Kingdom of France, Sweden and their respective allies, 24 October 1648,

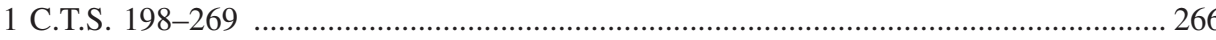

Treaty at Middle Plantation with tributary Indians after Bacon's rebellion, Articles of Peace,

29 May 1677

Articles of Peace and Amity with Piscawtaways, Mattawomans, and Chopticos, 14 May 1692

Peace and Friendship Treaty of Utrecht between France and Great Britain, 11 April 1713,

27 C.T.S. 475

Peace and Friendship Treaty of Utrecht between France and Portugal, 11 April 1713, 28 C.T.S. 169

Peace and Friendship Treaty of Utrecht between Spain and Great Britain, 13 July 1713,

28 C.T.S. 297

Peace and Friendship Treaty of Utrecht between Spain and Portugal, 6 February 1715,

29 C.T.S. 201

Treaty of Paris (1763 Treaty of Paris), between France, Great Britain and Spain, 10 February 1763, 42 C.T.S. 279 $183,267,276-7,279,283$

Definitive Treaty of Peace and Friendship between France and Great Britain, signed at

Versailles, 3 September 1783, 48 C.T.S. 437

Treaty of Peace between Great Britain and Spain, signed at Versailles, 3 September 1783 ,

48 C.T.S. 481 267,277

Definitive Treaty of Peace between Great Britain and the United States, 3 September 1783,

48 C.T.S. 487 277

Treaty of Amity and Alliance between the Dutch East India Co. (Netherlands) and Selangor, 6-13 August 1784, 49 C.T.S. 113 116,130

Definitive Treaty of Peace and Friendship between Great Britain and the Netherlands, signed at Paris, 20 May 1784, 49 C.T.S. 65

Treaty of Paris 1814, 30 May 1814, 63 C.T.S. 171, 1 B.F.S.P. $158 \ldots \ldots \ldots \ldots \ldots \ldots \ldots \ldots \ldots . . . .267-8,286$

Treaty of Paris 1815, 20 November 1815, 65 C.T.S. 301-32, 3 B.F.S.P. 280 ............ 267-8, 286

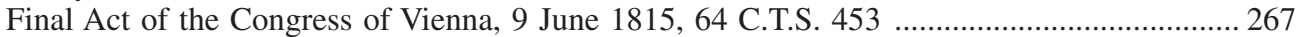

Engagement of King of North Bulloms. Cession of the Island of Tombo, 5 June 1821, 63 B.F.S.P. 
Treaty of Peace, Friendship, Limits and Settlement between the United States of America and the Mexican Republic (1849 Treaty of Guadalupe Hidalgo/1850 Convention of

Settlement), 2 February 1848,102 C.T.S. 29 $277-8$

Convention between the Argentine Confederation and Great Britain (Arana-Southern Treaty), signed at Buenos Aires, 24 November 1849, 103 C.T.S. 331 .................................. 278-9

Treaty of Limits between Costa Rica and Nicaragua signed at San José, April 15, 1858,

118 C.T.S. 439 418,433

Traité du 19 mai 1868 portant cession à la France du territoire de Kotonou par le roi de

Dahomey

Traité avec le Cayor [12 January 1871] 116,127

Treaty with the King of Quiah. Sovereignty. Retrocession. Boundaries. Open Roads.

Criminals. Slaves. Human Sacrifices. Trade. Religion. Benkia, 29 January 1872

Traité supplémentaire entre M. Stanley et les chefs du District de Palabala [19 Avril 1884]

Treaty No 3 of 2 December 1884 between Karl Peters and the Sultan Mbumi and Somwi,

Sultan of Msovero

Arrangement between Great Britain and Germany relative to their respective spheres of action

in portions of Africa, 29 April - 16 June 1885

Treaty of 21 June 1885 between Carl Jühlke and the Sultan Galassoni ................................. 131

Treaty between Carl Jühlke and the Sultan Hamolomo of 3 July 1885 ................................. 131

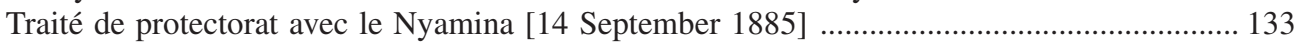

General Act of the Berlin Conference on West Africa, 26 February 1885,

165 C.T.S. 485

Protocole d'arbitrage relatif aux Carolines, signé à Rome [22 October 1885] ........................... 85

Convention d'acquiescement aux propositions du Pape [in the Carolinas dispute]

[17 December 1885]

Declaration between Germany and Portugal respecting the limits of their respective possessions and spheres of influence in South-West and South-East Africa, 30 December 1886 ..... 122

Agreement concluded between Great Britain and Germany, concerning East Africa (1 July 1890)

General Act of the Brussels Conference relating to the African Slave Trade, art. 1,

2 July 1890, 173 C.T.S. 293

Pan-American Conference on the Right of Conquest, 18 April 1890 ..................................... 437

Agreement between Great Britain and Portugal relative to spheres of influence north of the Zambesi, 31 May - 5 June 1893

Protocol between the French and German Delegates for the settlement of the questions pending between the two countries in the region comprised between the colonies of the Cameroons and French Congo; and to fix the line of demarcation of their respective spheres of influence in the region of Lake Chad, 4 February 1894

Traité de protectorat avec le roi Bant Chandé, Souverain du Gourma [20 January 1895] ..... 133

Convention between the United Kingdom and China respecting an extension of Hong Kong Territory, 9 June 1898

Treaty of Peace between Spain and the United States, signed at Paris, 10 December 1898, 187 C.T.S. 100 279-80, 286

Convention between Great Britain and France for the Delimitation of their respective possessions to the West of the Niger, and of their respective possessions and spheres of influence to the East of that River, Signed at Paris [14 June 1898]

Hague Convention (II) with Respect to the Laws and Customs of War on Land and its Annex: Regulations concerning the Laws and Customs of War on Land, art. 36, 29 July 1899, 187 C.T.S. 429 263

Treaty between Spain and the US for the Cession of Outlying Islands of the Philippines (1900 Treaty of Washington), 7 November 1900, 188 C.T.S. 120 
Treaty and Declaration between Great Britain and Brazil, for referring to arbitration the

Question of the Boundary between Brazil and British Guiana, 6 November 1901 ........ 294

Agreement between Great Britain and Japan relative to China and Corea, 30 January 1902,

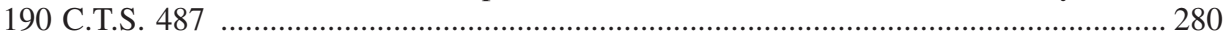

Peace of Vereeniging, 31 May 1902, 95 B.F.S.P. 160 ....................................................... 283

Agreement Between the United States and Cuba for the Lease of Lands for Coaling and

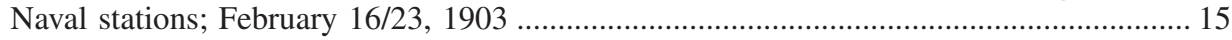

Cuban-American Treaty of Relations, 22 February 1903, 33 Stat. 2248 ................................ 149

1905 Taft-Katsura Agreement, 38(1) Dai Nippon Gaiko Bunsho (Diplomatic documents of

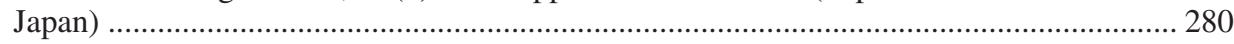

Treaty of Peace between Japan and Russia (Treaty of Portsmouth), 5 September 1905, 199

C.T.S. 144

Drago-Porter Convention 1907 (Second Hague Convention Respecting the Limitation of the

Employment of Force for the Recovery of Contract Debts)

Hague Convention (IV) Respecting the Laws and Customs of War on Land, with Annexed

Regulations, 18 October 1907 15,262

Protocol between Austria-Hungary and Turkey, 26 February 1909. 262

First Armistice at Compiègne, 11 November 1918, 224 C.T.S. 286 267,268

Treaty of Peace between the Allied and Associated Powers and Germany (Treaty of

Versailles), 28 June 1919, 225 C.T.S. 189 $267,268-9,283,287,317,318,319$

Covenant of the League of Nations, 1919 $14,22,149,343$

1919 Treaty of Saint-Germain-en-Laye, 10 September 1919, 226 C.T.S. 8 $317,318,319$

1919 Treaty of Neuilly-sur-Seine, 27 November 1919, 226 C.T.S. 333 269

1920 Peace Treaty of Tartu 379

1920 Treaty of Trianon, signed on 4 June 1920; entry into force 16 July 1920, 6 L.N.T.S. 188 $269,317,319$

Treaty of Sèvres, 10 August 1920, 113 B.F.S.P. 866 269,273

Protocol and Additional Article Regarding the Settlement of the Question of Western Hungary, 13 October 1921, 9 L.N.T.S. 203 319

Treaty of Peace between the Allied Powers and Turkey (Treaty of Lausanne), 24 July 1923, 28 L.N.T.S. 269, 273-4, 287, 288, 289

General Treaty for Renunciation of War as an Instrument of National Policy (Kellogg-Briand Pact), 27 August 1928, 94 L.N.T.S. 57 22-3, 236, 263

Treaty for the Settlement of the Dispute regarding Tacna and Arica, art. 2, 3 June 1929, 94 L.N.T.S 401

Convention between the U.S. and Great Britain Delimiting the Philippine Archipelago and the State of Borneo, 2 January 1930, T.S. No. 856 280

Convention on Rights and Duties of States (Montevideo Convention), 26 December 1933, 165 L.N.T.S. 19 $16,196,262,351$

Declaration Regarding the Defeat of Germany and the Assumption of Supreme Authority with Respect to Germany and Supplementary Statements (Berlin Declaration), 5 June 1945, 68 U.N.T.S. 190 271

Charter of the United Nations 24 October 1945, 1 U.N.T.S. XVI .......... 14, 20, 21, 23, 31, 113, $149,163,229,236,237,239,240,242,243-51,252,253,258,259,260,263,298,300$, $304,344,349,353,359,402,414,437$

Statute of the International Court of Justice, 1945 $6,9,18,196,415,434$

Treaty of Peace with Bulgaria, 10 February 1947, 41 U.N.T.S. 21 269-70 Treaty of Peace with Finland, 10 February 1947, 48 U.N.T.S. 203 Treaty of Peace with Hungary, 10 February 1947, 41 U.N.T.S. 644 Treaty of Peace with Italy, 10 February 1947, 49 U.N.T.S. 3 269-70 269-70 Treaty of Peace with Romania, 10 February 1947, 42 U.N.T.S. 135 1948 OAS Charter Universal Declaration of Human Rights, 1948 $269-70,283,284,288$ 269-70 304 330 
San Francisco Peace Treaty of 1951 [between Japan and Allied Powers], 8 September 1951, 136 U.N.T.S. 45 $264,267,280-83,285,286,290$

1952 Treaty of Peace between Japan and India, 9 June 1952

1952 Treaty of Peace with Japan, RoC-Japan (Treaty of Taipei), 28 April 1952, 163 U.N.T.S. 38 264,281

Military Armistice in Korea and Temporary Supplemental Agreement, 27 July 1953, 4 U.S.T. 234, 47, AM. J. INTL. L. Supp. 186 264

Treaty of Peace between the Union of Burma and Japan, 5 November 1954, 251 U.N.T.S. 201

1955 Treaty of Friendship Libya/France 221, 228

State Treaty for the Re-establishment of an Independent and Democratic Austria, 15 May 1955, 217 U.N.T.S. 223 270-71

Neutralitätserklärung [Declaration of Neutrality] Bundesverfassungsgesetz, 26 October 1955 (Austria)

Joint Declaration by the Union of Soviet Socialist Republics and Japan, 19 October 1956, 263 U.N.T.S. 99

Convention concerning the Protection and Integration of Indigenous and Other Tribal and

Semi-Tribal Populations in Independent Countries, 26 June 1957, 328 U.N.T.S. 247 ... 335

Treaty of Peace between Japan and the Republic of Indonesia, 20 January 1958, 324 U.N.T.S. 227

Antarctic Treaty, 23 June 1961, 402 U.N.T.S. 71 .................................................................... 8

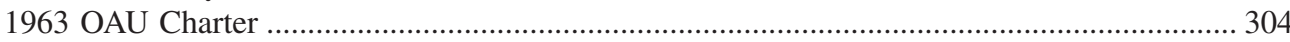

Organization of African Union Cairo Resolution, 1964 ............................................. 208, 385

International Covenant on Civil and Political Rights (CCPR), 16 December 1966, 999 U.N.T.S. 171 $298,330,360$

International Covenant on Economic, Social and Cultural Rights (CECSR), 16 December 1966, U.N.T.S 3 298, 330, 360

Vienna Convention on the Law of Treaties, 26 May 1969, 1155 U.N.T.S. 331 ... 170, 171, 172, $229,230,231,263,290$

Inter-American Convention of Human Rights, 22 November 1969, 1144 U.N.T.S. 123, OAS

Treaty Series No. 36 338

Treaty between Portugal and India, 31 December 1974, 982 U.N.T.S. 159 ............................. 183

Helsinki Conference on Security and Cooperation in Europe, Final Act, 1975 ......... 20, 21, 224, 304,353

Rules of the International Court of Justice, 1 July 1978 433,434

Treaty of Peace and Friendship between Japan and the People's Republic of China, 12 August 1978, 1225 U.N.T.S. 257 264,281

Vienna Convention on Succession of States in Respect of Treaties, 23 August 1978, 1946 U.N.T.S. 3 $135,224,229-30$

Framework for peace in the Middle East agreed at Camp David, 17 September 1978, 1138 U.N.T.S. 39 274

Framework for the Conclusion of a Peace Treaty between Egypt and Israel, 17 September 1978, 1138 U.N.T.S. 53

Treaty of Peace between the Arab Republic of Egypt and the State of Israel, 26 March 1979, 1138 U.N.T.S. 59

United Nations Convention on the Law of the Sea (UNCLOS), 10 December 1982, 1833

U.N.T.S. 397 $1,9,10,11,17,154,305,332,418$

1983 Constitution of Saint Christopher and Nevis 365

1984 Torture Convention 339

Exchange of notes between France and the Federal Republic of Germany of 10 May 1984, 89 R.G.D.I.P. 585-8 (1985) .14 Inuvialuit Final Agreement (as amended) (5 June 1984) 340 
Convention concerning Indigenous and Tribal Peoples in Independent Countries, 27 June 1989, 1650 U.N.T.S. 383

Treaty on the Final Settlement with Respect to Germany, 12 September 1990, 1696 U.N.T.S. 115

1991 Lithuanian-Russian Treaty

Agreement establishing the Community of Independent States signed at Minsk on

8 December 1991, 31 I.L.M. 143-6 (1992)

Alma Ata Declaration, 21 December 1991, attached to the Protocol to the Agreement establishing the Commonwealth of Independent States signed at Minsk on 8 December 1991 by the Republic of Belarus, the Russian Federation (RSFSR), and Ukraine, 31

I.L.M. 147, 148 (1992) $225,375,379$

European Charter for Regional or Minority languages, C.E.T.S. No. 148 (5 November 1992)

Treaty Between the Czech Republic and the Slovak Republic on Good Neighbourliness,

Friendly Relations and Cooperation, 23 November 1992, 1900 U.N.T.S. 115

1994 Constitution of Ethiopia 26,365

CIS Declaration on the Observance of Sovereignty, Territorial Integrity and Inviolability of Borders of States Members of the Commonwealth of Independent States of 15 April 1994

Treaty of Peace between the State of Israel and the Hashemite Kingdom of Jordan of 26

October 1994, 2042 U.N.T.S. 351, 34 (1) I.L.M. 46, 47 and 56-7 $14,275-6$

European Framework Convention for the Protection of National Minorities, C.E.T.S.

No. 157 (1 February 1995)

General Framework Agreement for Peace in Bosnia and Herzegovina (Dayton Agreement),

14 December 1995, 35 I.L.M. 89 $24,272,329$

African Union Constitutive Act, 11 July 2000, 2158 U.N.T.S. 3 208, 300, 304

Agreement between the Government of the Federal Democratic Republic of Ethiopia and the Government of the State of Eritrea (Algiers Agreement), 5 December 2000, 2138 U.N.T.S. 94 $254,283-4$

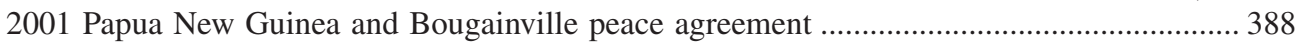

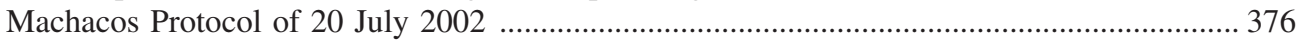

Treaty between Uzbekistan and Kazakhstan (9 September 2002) ........................................... 381

Protocol on the Resolution of the Abyei Conflict, signed by the Government of Sudan and the Sudan People's Liberation Movement/Army (26 May 2004) .................................... 383

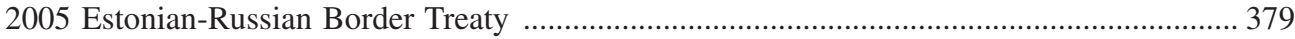

Interim National Constitution of the Republic of Sudan of 6 July 2005 ................................ 376

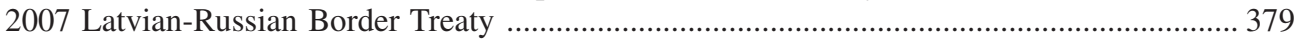

\section{B. Documents of International Organizations}

\section{League of Nations}

League of Nations Doc. R541/11/6906/1 (20 September 1920)

Report of the International Committee of Jurists entrusted by the Council of the League of Nations with the task of giving an advisory opinion upon the legal aspects of the Aland Island Question (Åland Report), League of Nations Doc. Special Supplement No. 3, at 5 (October 1920) $298,305,315,319,322$

Report presented to the Council of the League of Nations by the Commission of Rapporteurs (Åland Islands), League of Nations Doc. B7.21/68/106 (1921) $305,315,319,390$ 


\section{United Nations}

\section{a. General Assembly}

\section{RESOLUTIONS}

G.A. Res. 289 (IV), U.N. Doc. A/RES/289 (21 November 1949) 270

G.A. Res. 390 (V), U.N. Doc. A/RES/390 (V) (2 December 1950) 152,270

Declaration on the Granting of Independence to Colonial Countries and Peoples, G.A. Res. 1514 (XV), U.N. Doc. A/RES/1514 (XV) (14 December 1960)

Principles which should guide members in determining whether or not an obligation exists to transmit the information called for under Article 73e of the Charter, G.A. Res 1541 (XV), U.N. Doc. A/RES/1541(XV)

Declaration on the Inadmissibility of Intervention into the Domestic Affairs of states and the Protection of their Independence and Sovereignty, G.A. Res. 2131 (XX), U.N. Doc. A/RES/2131 (XX) (21 December 1965)

G.A. Res. 2066 (XX), U.N. Doc. A/RES/2066 (XX) (16 December 1965) (separation of the Chagos Archipelago from Mauritius)

G.A. Res. 2145 (XXI), U.N. Doc. A/RES/2145 (XXI) (27 October 1966)

Declaration on Principles of International Law concerning Friendly Relations and Co-operation among States in accordance with the U.N. Charter, G.A. Res. 2625, U.N. Doc. A/RES/25/2625 (24 October 1970) ......... 14, 15, 20, 21, 23, 108, 150, 224, 237, 238, $239,241,249,250,257,263,302,304,344,353,360$

G.A. Res. 2649 (XXV) (30 November 1970) 360

G.A. Res 3314 (XXIX), U.N. Doc. A/RES/3314 (14 December 1974) (Consensus Definition of Aggression) $252,258,263,350,353$

Declaration on the Rights of Persons Belonging to National or Ethnic, Religious and Linguistic Minorities, G.A. Res. 47/135, U.N. Doc. A/RES/47/135 (18 December 1992) ............... 304

G.A. Res. 33/24, U.N. Doc. A/RES/33/24 (29 November 1978) ............................................... 16

G.A. Res. 34/65, U.N. Doc. A/RES/34/65 (29 November 1979) ............................................. 274

G.A. Res. 36/103, U.N. Doc. A/RES/36/103 (9 December 1981) ............................................ 353

G.A. Res. 37/253, U.N. Doc A/RES/37/253 (13 May 1983) .................................................. 22

Declaration on the Enhancement of the Effectiveness of the Principle of Refraining from the Threat or Use of Force in International Relations, G.A. Res. 42/22, U.N. Doc. A/RES/42/22 (18 November 1987)

Declaration on the Rights of Indigenous Peoples, G.A. Res. 61/295, U.N. Doc. A/RES/61/295 (13 September 2007) …............................ 300, 303, 304, 335-6, 337, 364

The Human Right to Water and Sanitation, G.A. Res. 64/292, U.N. Doc. A/RES/64/292

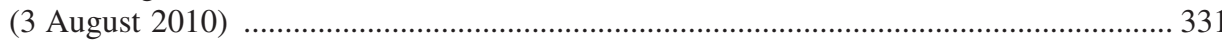

The Right to Food, G.A. Res. 68/177, U.N. Doc. A/RES/68/177 (18 December 2013) ......... 331 G.A. Res. 68/262, U.N. Doc. A/RES/68/262 (27 March 2014) ..................... 238, 291, 331, 350 Request to the International Court of Justice for an advisory opinion on the legal consequences of the separation of the Chagos Archipelago from Mauritius in 1965, in G.A. Res. 71/292, U.N. Doc. A/RES/61/295 (22 June 2017) 22,150

\section{LETTERS TO THE SECURITY COUNCIL}

Final Report on the Demarcation of the International Boundary between the Republic of Iraq and the state of Kuwait by the United Nations Iraq-Kuwait Boundary Demarcation Commission, in a letter dated 21 May 1933 from the Secretary-General addressed to the President of the Security Council, UN Doc. S/25811 (21 May 1993) 
Eritrea-Ethiopia Boundary Commission, Decision Regarding Delimitation of the Border, annexed to U.N. Secretary-General, Letter dated 15 April 2002 from the Secretary-General to the President of the Security Council, U.N. Doc. S/2002/423 (15 April 2002)

PROCÈS-VERBAL OF MEETINGS

U.N. GAOR, 49th Sess., 77th mtg. at 14, U.N. Doc. A/49/PV.77 (6 December 1994) 246

U.N. GAOR, 51st Sess., 77th plen. mtg. at 8, U.N. Doc. A/51/PV.77 (9 December 1996) .... 246

U.N. GAOR, 52nd Sess., 57th plen. mtg. at 12, U.N. Doc. A/52/PV.57 (26 November 1997)

U.N. GAOR, 53rd Sess., 69th plen. mtg. at 37, U.N. Doc. A/53/PV.69 (24 November 1998)

U.N. GAOR, 68th Sess., 33rd plen. mtg., U.N. Doc. A/68/PV.80 (27 March 2014) 350

\section{OTHER DOCUMENTS}

U.N. Secretary-General, An Agenda for Peace: Preventive Diplomacy, Peace-Making and Peace-Keeping: Rep. of the Secretary-General, 17, U.N. Doc. A/47/277-S/24111 (17 June 1992)

U.N. 1993 Vienna Declaration and Programme Action, U.N. Doc. A/CONF.157/24 (Part I) (25 June 1993)

\section{b. Security Council}

\section{SECURITY COUNCIL RESOLUTIONS}

S.C. Res. 242, U.N. Doc. S/RES/242 (22 November 1967) ........................................... 263, 275

S.C. Res. 389, U.N. Doc. S/RES/389 (22 April 1976) ............................................................. 16

S.C. Res. 502, U.N. Doc. S/RES/502 (3 April 1982) .................................................... 244, 245

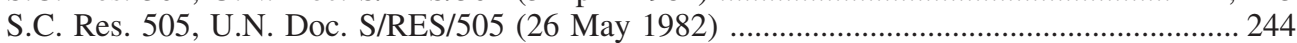

S.C. Res. 541, U.N. Doc. S/RES/541 (18 November 1983) ....................................................... 349

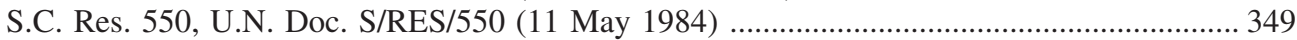

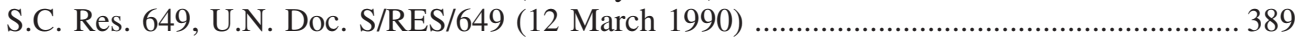

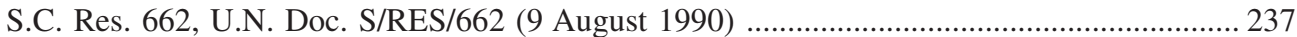

S.C. Res. 687, U.N. Doc. S/RES/687 (8 April 1991) ......................................... 225, 226, 328

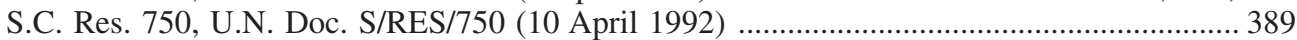

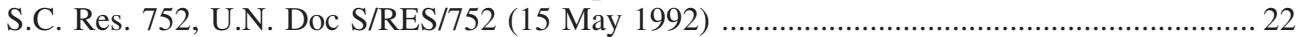

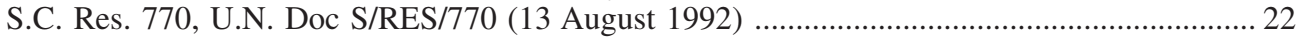

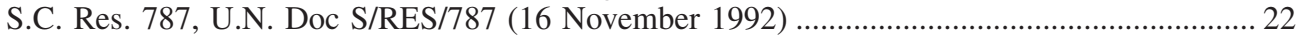

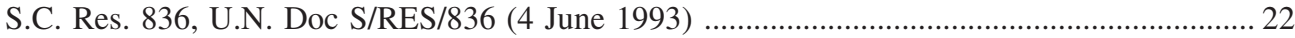

S.C. Res. 847, U.N. Doc S/RES/847 (30 June 1993) ......................................................... 22

S.C. Res. 859, U.N. Doc S/RES/859 (24 August 1993) .......................................................... 22

S.C. Res. 942, U.N. Doc S/RES/942 (23 September 1994) ................................................... 22

S.C. Res. 956, U.N. Doc. S/RES/956 (10 November 1994) ..................................................... 149

S.C. Res. 963, U.N. Doc. S/RES/963 (29 November 1994) ................................................... 149

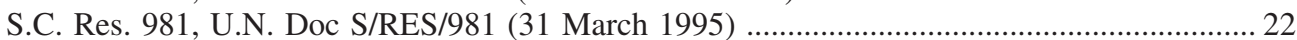

S.C. Res. 982, U.N. Doc S/RES/982 (31 March 1995) ........................................................... 22

S.C. Res. 1160, U.N. Doc S/RES/1160 (31 March 1998) ....................................................... 22

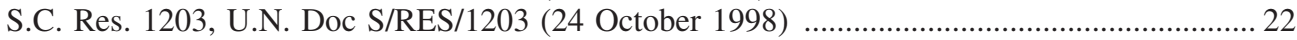

S.C. Res. 1244, U.N. Doc S/RES/1244 (10 June 1999) .................................................. 22, 363

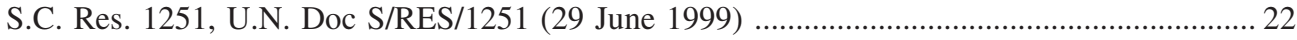

S.C. Res. 1756, U.N. Doc S/RES/1756 (15 May 2007) ......................................................... 22

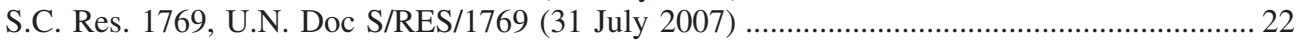




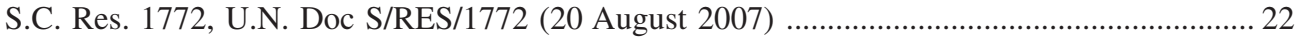

S.C. Res. 1781, U.N. Doc S/RES/1781 (15 October 2007) .................................................... 22

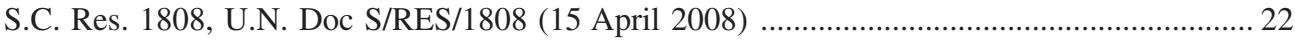

\section{RECORD OF MEETINGS}

U.N. SCOR, 987th mtg., U.N. Doc. S/PV.987 (18 December 1961)

247,253

U.N. SCOR, 988th mtg., U.N. Doc. (18 December 1961) $247,248,252$

U.N. SCOR, 2345th mtg., U.N. Doc. S/PV.2345 (1 April 1982)

U.N. SCOR, 2346th mtg., U.N. Doc. S/PV.2346 (2 April 1982)

U.N. SCOR, 2349th mtg., U.N. Doc. S/PV.2349 (2 April 1982)

U.N. SCOR, 2350th mtg., U.N. Doc. S/PV.2350 (3 April 1982) 245,249

U.N. SCOR, 2934th mtg. at 46, U.N. Doc. S/PV.2934 (9 August 1990)

U.N. SCOR, 2981st mtg. at para 7, U.N. Doc. S/PV.2981 (3 April 1991) ................................ 225

U.N. SCOR, 3007th mtg. at 4-5, U.N. Doc. S/PV.3007 (15 September 1991) ......................... 238

U.N. SCOR, 3256th mtg. at 14-16, U.N. Doc (20 July 1993) .............................................. 380

U.N. SCOR, 7138th mtg., U.N. Doc. (15 March 2014) ................................................. 350, 360

\section{LETTER AND STATEMENT OF THE PRESIDENT OF THE SECURITY COUNCIL}

U.N. Security Council, Note by the President of the Security Council, Annex, Letter dated 20 January 1974 from the Permanent Observer of the Republic of Vietnam to the United Nations addressed to the President of the Security Council, U.N. Doc. S/11200 (21 January 1974)

U.N. President of the S.C., Statement by the President of the Security Council, U.N. Doc. S/14944 (1 April 1982)

\section{c. Committee on Economic, Social and Cultural Rights}

U.N. Committee on Economic, Social and Cultural Rights, General Comment 12: The right to adequate food (Art. 11), UN Doc. E/C.12/1999/5 (12 May 1999)

Committee on Economic, Social and Cultural Rights. General Comment 15: The right to water (Arts. 11 and 12), UN Doc. E/C.12/2002/11 (20 January 2003)

\section{d. International Law Commission}

Survey of International Law in Relation to the Work of Codification of the International Law Commission: Preparatory work within the purview of article 18, paragraph 1, of the International Law Commission - Memorandum submitted by the Secretary-General, paras. 64-7, U.N. Doc. A/CN.4/1/Rev (10 February 1949)

Draft Articles on the Responsibility of States for Internationally Wrongful Acts, Rep. of the Int'l Law Comm'n, 53rd Sess. 23 April - 1 June and 2 July - 10 August 2001, U.N. Doc. A/56/10, GAOR 56th Sess., Supp. No. 10 (2001) $159,171,173,252,353$

Eighth Report on Unilateral Acts of States, by Mr Victor Rodriguez Cedeño, Special Rapporteur, 57th Sess. 2 May - 3 June and 4 July - 5 August, 2005, U.N. Doc. A/CN.4/557 (26 May 2005)

Guiding Principles Applicable to Unilateral Declarations of States Capable of Creating Legal Obligations, with commentaries, Rep. of the Int'l Law Comm'n, 58th Sess. 1 May - 9 June and 3 July - 11 August 2006, principle 4, U.N. Doc. A/61/10, GAOR, 61st Sess., Supp. No. 10 (2006) 172,173

\section{e. Trusteeship Council}

U.N. Doc. T/RES/2199 (LXI) (25 May 1994) 149 
$\mathrm{xx}$ Research handbook on territorial disputes in international law

\section{International Labor Organizations}

International Labour Org. Conf., Partial Revision of the Indigenous and Tribal Populations

Convention, Report VI(1), 1957 (No. 107), 76th Sess. (1989) 335

\section{African Union}

Org. African Unity, Border Disputes Among African States, AHG/16 (I) (21 July 1964),

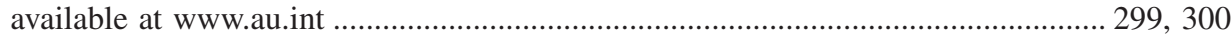

Org. of African Unity, Doc. Assembly/AU/Dec. 141 (VIII) (30 January 2007) ...................... 337

African Commission on Human and Peoples' Rights, Advisory Opinion of the African

Commission on Human and Peoples' Rights on the United Nations Declaration on the

Rights of Indigenous Peoples, 41st Ordinary Sess. (May 2007) ....................................... 303

\section{European Union}

Communication from the Commission on the European Citizens' Initiative, 'Water and sanitation are a human right! Water is a public good, not a commodity!', COM (2014)

177 final (19 March 2014), available at

http://ec.europa.eu/transparency/com_r2w_en.pdf

European Community, DECLARATION AT THE BRUSSELS EC MEETING, 27 AUGUST

1991, 62 BRIT. Y.B. INT'L L. 558 (1991) ..................................................................... 238

\section{Organization of American States}

Draft American Declaration on the Rights of Indigenous Peoples, Fourteenth Meeting of

Negotiations in the Quest for Points of Consensus: Record of the Current Status of the

Draft American Declaration of the Rights of Indigenous Peoples, OEA/Ser.K/XVI, Doc.

GT/DADIN/doc.334/08 rev. 7 (2 May 2012)

Follow-up Report - Access to Justice and Social Inclusion: The Road towards Strengthening

Democracy in Bolivia, Inter-Am. Comm'n H.R., OEA/Ser/L/V/II.135, Doc. 40 (28 June

2007)

Indigenous and Tribal Peoples' Rights over their Ancestral Lands and Natural Resources.

Norms and Jurisprudence of the Inter-American Human Rights System, OEA/Ser.L/II.

Doc.56/09 (30 December 2009), available at

http://cidh.org/countryrep/Indigenous-Lands09/TOC.htm

OAS, OEA/Ser.K/XVI, Doc. GT/DADIN/doc.193/03 (17 June 2003)

OEA/Ser.K/XVI, Doc. GT/DADIN/doc.334/08 rev. 7 (2 May 2012)

\section{Other Documents}

Resolution 2: Frontiers, Boundaries and Federations adopted by the All-African Peoples

Conference, Accra 5-13-1958

\section{Official Documents of States and Other International Entities}

\section{China}

China, Letter dated 21 January 1974 from the Permanent Representative of China to the United Nations addressed to the President of the Security Council, 2, U.N. Doc. S/11201 (21

January 1974) 
China, Letter dated 20 April 1987 from the Permanent Representative of China to the United Nations addressed to the Secretary-General, U.N. Doc. A/42/236 - S/18818 (21 April 1987)

China, Letter dated 13 May 1988 from the Permanent Representative of China to the United

Nations addressed to the Secretary-General, U.N. Doc. A/43/363 - S/19887 (16 May 1988)

\section{Croatia}

Statement attributed to Ambassador Andreja Metelko-Zgombic, Head of the Independent Service for International Law, Ministry of Foreign Affairs of Croatia, in OSCE, 'Applied Issues in International Land Boundary Delimitation/Demarcation Practices - A Seminar organized by the OSCE Borders Team in co-operation with the Lithuanian OSCE Chairmanship, 31 May to 1 June 2011, Vilnius, Lithuania' (OSCE: Vienna, 2011) 377

\section{France}

Lettres patentes accordez à François de la Roque, Seigneur de Roberval [1540]

The King of Portugal's Claim to the Guinea Trade, 20 May 1562 .70

Letter of the Cardinal of Toledo to the Emperor Charles V relating to the answer given by François I of France on Spanish protests [1580]

Lettres patentes accordées par le Roi Henri IV de France au Sieur De Monts, le 8 novembre 1603 126,131

Déclaration du Roy portant établissement d'une compagnie pour le commerce des Indes orientales, 1er septembre 1664

Indes orientales au gouvernement portugais [1698]

Report of the Diplomatic Committee on the Family Compact betwixt the French and Spanish Branches of the House of Bourbon addressed to the National Assembly by M. Mirabeau, 1790

Mémoire pour établir les droits du Roi sur l'isle de Sainte-Lucie remis aux commissaires de sa Majesté Britannique le 11 février 1751

Loi approuvant le traité passé avec le roi Makoko, 30 novembre 1882 ............................... 120

M. Jules Ferry, président du Conseil, ministre des Affaires étrangères, au baron de Courcel, ambassadeur de la République française à Berlin, le 8 novembre 1884 ........................... 82

Rapport adressé au ministre des Affaires étrangères de France, par M. Ed. Engelhardt, ministre plénipotentiaire, délégué à Berlin, pour la conférence africaine [1885] ............ 111

Baron d'Estournelles to the Marquis of Salisbury, October 27, 1891

M. Waddington to the Marquis of Salisbury, 30 December 1891

Décret du 10 juin 1887 ratifiant les traités du 4 juillet 1843 et 26 mars 1844, par lesquels Atacla et son successeur, Amatifou, rois d'Assinie, assistés de leurs principaux chefs, ont concédé à la France, la souveraineté pleine et entière de tout leur territoire ......

Décret du 1er août 1895, portant ratification des traités passés dans l'Afrique occidentale par MM. Decoeur, Mounier, Baud, Alby et Deville

Décret du 6 octobre 1897 portant ratification les traités passés au nord de la Côte d'Ivoire et du Dahomey

Décret du 1er décembre 1897 portant ratification de traités passés dans la boucle du Niger

Décret du 23 mai 1889 portant approbation de traités conclus avec les chefs des rivières du Sud

Décret du 23 mai 1889 portant ratification de traités conclus avec des chefs indigènes du Sénégal

Boundary between French and Liberian Possessions, 8 December 1892 


\section{xxii Research handbook on territorial disputes in international law}

Décret du 6 octobre 1897 portant ratification les traités passés au nord de la Côte d'Ivoire et du Dahomey

La situation des établissements français à la Côte des Esclaves. Discussion à la Chambre des députés, séance du 8 mars 1819: Réponse de M. Étienne, sous-secrétaire d'État aux Colonies

Ministre des Colonies de la France: Note sur les coutumes des populations sahariennes en matière d'arrangements contractuels et les droits respectifs de la France et de l'Espagne sur l'Adrar occidental [1900] 131,132

\section{Germany}

Charter of the German Company of New-Guinea of 17 May 1885 76

Mémoire relatif aux territoires placés sous le Protectorat de l'Empire allemand, présenté au Reichstag par le Chancelier de l'Empire Prince de Bismarck le 2 décembre 1885 126 Annex I of Reichskanzleran an den Generalkonsul Dr. Nachtigal. - Auftrag gewisse Küstenstriche unter deutsches Protectorat zu stellen [19 May 1884] 119

\section{Great Britain}

First Letters Patent granted by Henry VII to John Cabot and His Sons, 5 March 1496 ... 50, 51, $65,66,69,102$

Letters Patent to Richard Warde, Thomas Ashurst, and John Thomas of Bristol and to John Fernandez, Francis Fernandez and John Gonzales of the Azores, 19 March 1501 .......... 66,

Letters Patent to Hugh Eliot, Thomas Ashurst of Bristol and John Gonzales and Francis

Fernandez of the Azores, 9 December 1502 .................................................................66-7

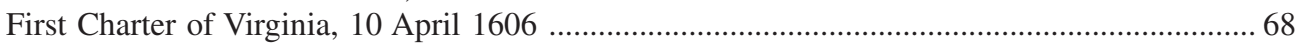

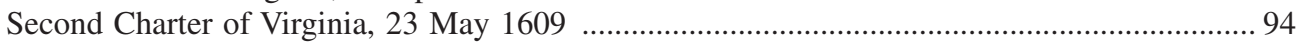

Third Charter of Virginia, 12 March 1611 .......................................................................... 94

Charter in favour of Sir William Alexander, Knight, of the Lordship and Barony of New

Scotland in America, 10 September 1621 .......................................................... 104, 126

Cromwell's Declaration on the Justice of the War against Spain, 26 October 1655 .......... 53, 80,

Charte octroyée par le roi Charles II d'Angleterre à la colonie du Rhode-Island et des plantations de Providence, le 8 juillet 1663 ................................................................ 120

Letters Patent granted to the Governor and Company of Merchants of London, Trading into the East Indies, 27 March 1669

Mémoire confidentiel adressé au Duc de Wellington par le Comte Lieven, 23 November 1822

The Marquis of to Captain HOBSON, R.N. SIR, 14 August 1839 ............................................. 133

Charter granted to the National African Company Limited, 10 July 1886 ............................... 120

The Marquis of Salisbury to the Marquis of Dufferin, 30 March 1892 .................................. 112

\section{Italy}

Statement of the Minister of Foreign Affairs of Italy, Mancini, before the Italian Parliament, 26 June 1882: AP, CD, Discussioni, tornata 26 giugno 1882, 2 LA PRASSI ITALIANA DI DIRITTO INTERNAZIONALE: PRIMA SERIE (1861-87), doc. 840 (1970) ............... 119 Explanation of the Italian Minister of Foreign Affairs before the Consiglio del Contenzioso Diplomatico (1979) 


\section{Netherlands}

Charter of the States General for the United Netherlands East India Company, 20 March 1602 118

Answer of Director Stuyvesant and Council to the preceding protest of Hendrick Van

Elswyck Swedish Factor, 27 October 1654 122,123

Translation of the Journal of the Dutch Commissioners to Hartford, 15 October 1663 ........... 58

\section{Papacy}

Letter of Pope Innocent IV to the King of the Tartars (5 March 1245)

The papal bull Romanus Pontifex of 1436 62

The Bull Romanus Pontifex (Nicholas V), 8 January 1455 ... 50,56

The Bull Inter caetera (Calixtus III), 13 March 1456 $45,46,63,101$

The Bull Eximiae devotionis (Alexander VI), 3 May 1493 ... 102

The Bull Dudum siquidem (Alexander VI), 26 September 1493 $43,44,45,98$

The Bull Inter Caetera (Alexander VI), 4 May 1493 $43,44,45,48,49,50-57,63,66,79$, $85,87,98,102,105,142$

The papal bull Dum Diversas of 1452 45,101

The Bull Ineffabilis of Pope Alexander VI granting to the Catholic Kings the investiture of

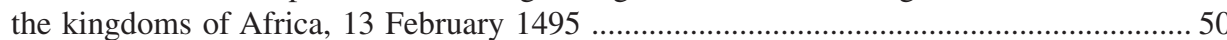

Bull Eximiae Devotionis of 3 May 1493 ................................................................ 43, 45

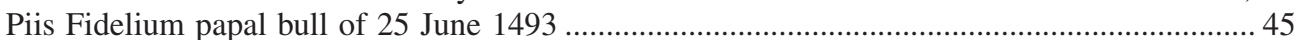

The papal bull Eximiae Devotionis of 3 May 1496 ................................................................. 45

The papal bull Ineffabilis of 1 June 1497 ......................................................................47, 103

The Bull Praecelsae Devotionis (Leo X), 3 November 1514 ............................. 45, 46, 47, 102

\section{Portugal}

Letter by King Alphonso IV of Portugal to Clement VI concerning the Enfeoffment of Luis de

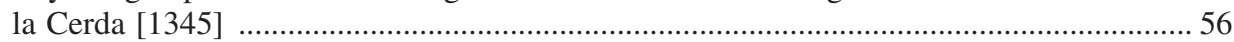

Letter from King Duarte I of Portugal to Pope Eugenius IV, Vatican Archives, Reg. Lat. 336, Folio 189 [August 1436] ................................................................................................. 56

Charter of King Alfonso V to Joâo Vogado granting him two islands, Louo and Capraria, 29 February 1462

Decree of February 11, 1891, granting a Charter to the Mozambique Company, as modified by the Decree of 30 July 1891

\section{Spain}

Lettre de créance de Colomb [adressée au Grand Khan], 30 avril 1492

Lettre à Luis de Santángel, février-mars 1493 54

Extract from a Dispatch of Ferdinand and Isabella to Gonzales de Puebla, Their Ambassador in England, 28 March 1496

Requerimiento (Proclamation read to the American-Indian natives by the Conquistadores after their landing), 1513 49, 98, 114

Instruccion que dio el capitan Velasquez, en la isla Fernandina al capitan Hernan Cortes (...) (23 Octobre 1518)

Espagne Décret royal du 23 décembre 1885 76, 119 


\section{Sweden}

Charter of Privileges, which the Mighty and Most Noble Prince and Lord, Gustavus Adolphus, King of Sweden, Gothland and the Wendes, Grand Duke of Finland, Duke of Esthonia and Carelia, Lord of Ingermanland, etc has graciously given by letters patent to the newly established Swedish South Company, 4 June 1626 118

\section{United States of America}

Note of the United States Secretary of State, Stimson, to Japan and China on the

Non-Recognition of Territorial Acquisitions by Conquest, 7 January 1932

The General Framework Agreement for Peace in Bosnia and Herzegovina, in a letter dated 29

November 1995 from the Permanent Representative of the United States of America to the United Nations Secretary-General, UN Doc. A/50/790-S/1995/999 (30 November 1995)

\section{Vietnam}

Vietnam, Letter dated 2 May 1988 from the Cargé d'affaires a.i. of the Permanent Mission of Vietnam to the United Nations addressed to the Secretary General, U.N. Doc. A/43/346 S/19836 (2 May 1988)

\section{Yugoslavia}

Letter dated 15 March 2001 from the Permanent Representative of the former Yugoslav

Republic of Macedonia to the United Nations addressed to the Secretary-General, UN

Doc. A/56/60-S/2001/234 (16 March 2001)

\section{Acts of diplomatic conferences}

Protocol No 2 Session of 19 November 1884

Protocol No 8, Session of 31 January 1885 